\title{
O DIREITO ADMINISTRATIVO E OS TRIBUNAIS
}

\author{
Roscoe Pound
}

SUMARIO: Definições do direito administrativo - $O$ papel da revisão judicial - Perigo do exercício da função jurisdicional pelas agências administrativas - Abuso dos poderes administrativos.

* Quando nos referimos a direito administrativo, grande parte do significado dessa expressão fica a depender do que entendemos por direito. Alguns dos mais enfáticos defensores da concessão de ilimitados poderes às agências administrativas, para que elas façam o que quiserem, da maneira qưe melhor lhes convier, sustentam que o direito significa apenas tudo quanto se faz oficialmente. Daí, - concluírem que os atos de tais agências são necessàriamente legais, pelo simples fato de serem delas oriundos. Outros existem que, esposando opiniōes importadas do continente europeu, consideram as legislaturas e a instância administrativa como juízes finais de seus próprios poderes, e, as agências administrativas, intérpretes últimos das leis para cuja aplicação foram criadas. Para êles, afigura-se inteiramente despropositada qualquer interferência dos tribunais ordinários, quer no poder de regulamentação das autoridades administrativas, quer no exercício da função jurisdicional das mesmas.

Não foi êsse o sistema político implantado na América ao alvorecer da Declaração da Independência. Não foram essas as iđéias em cujo seio os juristas americanos se formaram. Não foi essa a teoria de govêrno proclamada na Declaração de Direitos de Massachusetts.

Não se faz mister demonstrar aos juristas de Massachusetts que os funcionários públicos, embora a pretexto de agirem oficialmente, podem, na realidade, agir de acôrdo com o direito, sem o direito, ou contra o direito. Desnecessário demonstrar-lhes que nenhuma agência administrativa, em nosso sistema político, se acha colocada acima de qualquer funcionário ou que nenhum funcionário

* Discurso proferido perante a Ordem dos Advorados de Massachusetts, em maio de 1944. Traduzido de State Government, setembro de 1944, vol. XVII, n. 9, por Guilherme Augusto dos Anjos e Braulino Botelho Barbosa. 
está situado acima do cidadão comum no tocante à obrigação de observarem as leis do país, tais como são interpretadas e declaradas pelos tribunais no curso de litígio regular, no qual tôda ação nociva aos direitos de outrem é suscetível de ser examinada quanto à sua conformidade ou falta de conformidade com as exigências do direito. Nesse sentido, não há, em nosso sistema, direito administrativo que estabeleça distinção entre as agências administrativas e as pessoas em geral. Com efeito, Blackstone, ao tratar do direito público, subordina-o ao direito privado das pessoas.

Definições de "Direito Administrativo" - O direito administrativo poderia, portanto, significar os princípios processuais aplicados pelas agências administrativas no exercício de seus poderes jurisdicionais. Isso, porém, é algo que a maioria delas ainda não realizou. Ou poderia significar, talvez, o conjunto de preceitos e a técnica de desenvolvê-los e aplicá-los no exame judicial ou na revisão judicial de decisões administrativas. Neste ponto, seja como fôr, podemos encontrar algo com as características que os juristas costumam atribuir ao direito.

O que é preciso considerar, qualquer o nome que the possamos atribuir, é não só a relação entre os tribunais e o exercício das chamadas funções quase-judiciais por parte das agências administrativas, como também tudo quanto seja necessário para que a legislação torne os tribunais realmente capazes de assegurar, aos indivíduos, os direitos garantidos pelas nossas Cartas Constitucionais, isto é, as bases de uma investigação completa e imparcial, feita por tribunal equânime, e decisões consentâneas àquelas leis permanentes, que a Declaração de Direitos de Massachusetts reclamara e que a Declaração de Direitos do Congresso Continental proclamou como sendo o direito de emancipação dos americanos. Nosso problema te assegurar tudo isso, sem detrimento da eficiência das agências administrativas no legítimo setor de suas legítimas atividades.

De certo ponto de vista, poder-se-ia dizer que o advento dos tribunais administrativos e da função jurisdicional exercida pelas uutoridades administrativas, nos Estados Unidos, coincidira com a criação, em 1887, da Comissão de Comércio Interestadual. Nos Estados, entretanto, já se havia manifestado pelo menos dez anos antes. Já em 1880 começara a se fazer notar nos tribunais uma atitude diferente para com a administração. Tornara-se necessária, com o desenvolvimento da administração numa sociedade que se urbanizava e industrializava cada vez mais. Em nosso primitivo sistema político, a tradicional animosidade entre o direito consuettudinário e a administração, desenvolvida na Inglaterra com as lutas entre os tribunais e os reis Stuarts, reforçada na América pela experiência de 
governadores reais, que executavam instruçōes emanadas da Inglaterra, e alimentada pela desconfiança que as sociedades pioneiras votavam à administração, tomou forma numa concepção excessivamente estreita da separação dos poderes, que provou ser impraticável na transição de uma sociedade aldeã e agrícola para outra urbana e industrial. A solução fôra indicada, há mais de cem anos, pelo Ministro Marshall, da Suprema Côrte. Ele demonstrou a existência de poderes governamentais de classificação dúbia, que poderiam ser enquadrados, adequadamente, em mais de um dos ramos constitucionais de govêrno, e que, em tais casos, a classificação do poder em um dos ramos adequados constituía função própria do legislativo. Demonstrou isso $\mathrm{ccm}$ referência às normas de processo adotadas nos tribunais. Mais tarde, êsse critério veio a ser firmado na regulamentação dos serviços de utilidade pública, no tocante ao poder de fixar tarifas. Mais recentemente, a aplicação de normas que envolvesse arbítrio, ou julgamento com respeito à justiça, veio a ser confiada às agências administrativas pela legislacão, e os tribunais reconheceram que isso era conforme com o princípio exposto pelo Ministro Marshall, da Suprema Côrte. Na última década do século dezenove e na primeira dêste século, verificou-se um constante aumento de agências administrativas nos Estados, em consequiência do advento da legislação social. A princípio, isso causou certo atrito com os tribunais. Alguns tribunais estaduais obstinaram-se em manter um estreito ponto de vista analítico da separação dos poderes, não dando aprêço à doutrina de MARSHall, de sorte que, já em pleno século atual, legítimos poderes das agências administrativas eram, por vêzes, julgados inconstitucionais. Isso levou alguns defensores da expansão administrativa a denunciarem a separacão dos poderes, considerada como fundamental no direito constitucional americano. Além disso, o nosso direito consuetudinário, tal como o recebêramos da Inglaterra dos séculos dezessete e dezoito, era muito rigcroso quanto a tribunais de jurisdição especial ou limitada. Essa não se exercia abusivamente. Os' fatos que lhes davam jurisdição deviam ser circunstanciadamente expostos e os erros oriundos da inobservância das normas processuais, estabelecidas pela lei que os criou, bastariam para invalidar as suas decisões. A menos que satisfizessem estritamente essas exigências, suas deliberações podiam ser cassadas. Em consequiência disso, quase tôdas as deliberações ou medidas administrativas de alguma importância eram obstadas por embargos judiciais. Essa situação foi agravada pelo desenvolvimento demorado de recursos mais simples, por meio da revisão judicial das decisões administrativas de natureza jurisdicicnal. Ainda não se havia atinado em aplicar às agências administrativas, que estavam sendo criadas, os recursos utilizados pelo direito 
consuetudinário na revisão de atos administrativos, parecendo muito provável que a revisão por processo de eqüidade, a que era mister recorrer na ausência de outro recurso adequado, tivesse o efeito concomitante de substituir o arbítrio da agência administrativa pelo do tribunal. $O$ que causava certa irritação era as agências administrativas terem de sujeitar-se a uma observância estrita das normas próprias aos processos do júri, e das idéias processuais do direito consuetudinário. De fato, as condiçōes do processo judicial, no último quartel do século dezenove, estavam longe de ser satisfatórias sob muitos aspectos, e não se adaptavam bem à revisão das decisões administrativas.

Uma atitude mais liberal para com as agências administrativas pode ser notada já em 1880. Na primeira década do século atual, ccmeçou a surgir uma nova atitude para com a legislação social, paralelamente a um constante aperfeiçoamento da processualística judiciária, de sorte que, aos poucos, foram desaparecendo as condições que predominavam no último quartel do século dezenove. Não obstante, as tentativas das agências administrativas para conseguirem independência jurídica e exame judicial de seus próprios atos continuaram a se fazer sentir, como se ainda persistissem o processo jurídico da década dos 90 e a atitude judicial do último século.

Quando remontamos às origens do direito administrativo americano, podemos compreender perfeitamente como é que se procurou corrigir os abusos decorrentes do desajustamento entre a lei e a administração, e entre os tribunais e as agências administrativas. Assim, as legislaturas e as agências administrativas excederam-se algumas vêzes, dando lugar a um crescente absolutismo administrativo, que foi objeto de atenção geral, durante o regime de proibição, e que se tornou, a partir daí, sério problema. Observa-se, já em 1907, uma tendência para libertar as agências administrativas da revisão judicial, onde e tanto quanto fôsse possível. Hoje em dia, tôdas as agências administrativas federais parecem ambicionar isenção de exame judicial para os seus atos, sendo essa isenção aconselhada, com insistência cada vez maior, por um grupo de autores e mestres. Em consequiência disso, com a multiplicação dessas agências no govêrno federal, com a crescente sujeição de tôdas as formas de atividade à regulamentação administrativa, e com a hostilidade das agências administrativas a qualquer tentativa para se lhes impor contrôles jurídicos efetivos, atingimos uma situação de absolutismo administrativo na prática, e estamos caminhando ràpidamente para o absolutismo administrativo na teoria. Isso corresponde a um movimento quase revolucionário no sistema político americano, e alguns professores universitários não hesitam mesmo em declará-lo uma revolução e louvá-lo como tal. 
O papel da revisão judicial - A solução administrativa dos litígios surgidos, em nosso país, na geração contemporânea, apresenta certos aspectos gerais que clamam por uma revisão judicial efetiva, se é que deve ser mantido o nosso sistema jurídico e constitucional.

Esses aspectos demonstram não só a falta de contrôle sôbre as decisões administrativas, como ainda a falta de qualquer "espírito de decisão", que, de algum modo, se possa comparar àquele "espírito de adjudicação", desenvolvido e mantido nos tribunais judiciários.

Lembremo-nos dos contrôles que, atuando sôbre os tribunais, entretanto não prevalecem, nem são eficazes em nossa prática, com relação às agências administrativas. Quatro dêsses contrôles são significativos. Em primeiro lugar, num tribunal, os juízes são induzidos, desde o início de sua carreira, a moldar os seus atos a certos padrões conhecidos e a submeterem-se a preestabelecidos ideais de conduta forense. $O$ hábito e o treinamento profissionais obrigam-nos a ouvir escrupulosamente os lados opostos de cada questão; e os principios de direito, entranhados em seus hábitos de ação cotidiana, forçam-nos $a$ insistir em que tudo quanto lhes possa servir de base para sentenças ou julgamentos lhes seja apresentado de forma tal que nenhum litigante se veja privado da oportunidade ampla de explicá-lo, refutá-lo, ou de objetar sua aplicação ao caso em lide. Juízes e tribunais, antes de proferirem suas sentenças, são obrigadcs, em cada caso, a procurar os fundamentos positivos para a decisão, e a basear seus atos na argumentação decorrente de tais fundamentos. Além disso, a decisão de um tribunal está sujeita à crítica de uma classe instruída, a cuja opinião os juizes, na qualidade de componentes da mesma, são profundamente sensiveis. Em terceiro lugar, tôdas as sentenças e os casos sôbre os quais foram proferidas figuram, na integra, em documentos oficiais. Nesses documentos, qualquer pessoa pode descobrir exatamente quais foram as alegações das partes respectivas, quais as questões de fato e de direito discutidas perante o tribunal, e como as questões de fato foram julgadas - se por um júri, com quesitos oportunos, propostos pelo tribunal e especificamente respcndidos; se por um juiz, na forma de averiguações especiais de fato. Do mesmo modo, quaiquer pessoa poderá descobrir, por êsses documentos, quais as conclusões a que chegou o tribunal quanto à lei aplicável, seja por meio de instruções ao júri, ou através de averiguações pelo tribunal. Além disso, o julgamento do tribunal deve corresponder às alegações, às averiguações de fato e às conclusões de direito, e qualquer falta de conformidade com êsses pontos estará evidente nos autos. Em quarto lugar, tôdas as sentenças emanadas de um juiz individual estão sujeitas à revisão por parte de um grupo de juízes, independente daquele cuja ação deve ser exa- 
minada, e não constrangido, por qualquer organização hierárquica ou esprit de corps, a concordar com aquelas decisōes individuais. Isso, porém, ainda não é tudo. No caso dos tribunais de apelação, tôdas as suas decisóes importantes e os fundamentos em que se baseiam, bem como as razões de que se valem para proferir suas sentenças, são publicados em relatórios forenses. As opiniões devem basear-se nos registros dos casos decididos, e êsses registros são documentos públicos acessíveis a qualquer pessoa. Assim, os elementos para crítica e apreciação exata das decisōes judiciais estão sempre disponíveis e podem ser prontamente consultados. Não há tais contrôles, no prccesso administrativo.

Façamos uma comparação. Aquêles que se ocupam em proferir decisōes administrativas raras vêzes tiveram experiência na função de julgar. A experiência que se pode dêles exigir é inteiramente diversa. Talvez esposem a opinião vuigar de que a decisão é tarefa por demais fácil para que exija experiência adquirida através de tirocínio regular, e sejam, também, deliberadamente ignorantes de uma das primeiras coisas que um jurista aprende, isto é, de que há dois lados em cada questão. Sem cultura adequada para fundamentar seus atos segundo determinados padrões, èles são propensos a julgar os casos como se fôssem unilaterais, justamente como, talvez, procederiam, embora de maneira correta, em suas funções de mando. Além disso, o número dos que são competentes para criticar as decisões administrativas, que se não enquadram no curso geral dos atos administrativos, é realmente multo limitado, se não levarmos em conta os juristas. Não são, necessàriamente, membros de uma profissão comum à dos funcionários administrativos, e, por isso, não é provável que êstes últimos considerem como imerecedoras de atenção a sua crítica e a dos juristas. Em terceiro lugar, as decisões administrativas não săo salvaguardadas pelos documentos detalhrados e explícitos que subjugam qualquer tendência para desviar os tribunais de uma ação imparcial e objetiva, ao proferirem suas sentenças, e que permitem, tanto ao jurista quanto ao leigo, conhecer exatamente a natureza, o modo e a causa de um determinado ato. Em quarto lugar, como será mostrado em breve, a revisão das decisões administrativas por funcionário administrativo é coisa muito diversa da revisão do ato de um juiz por um tribunal de justiça independente.

Alega-se que a simplicidade do processo e a falta de métodos técnicos constituem as vantagens da justiça administrativa. Porém, nas mãos de agências e subordinados de agências, não dispostos a ser escrupulosamente retos, êsses métodos simples e empíricos podem servir, fàcilmente, de armadilhas para o cidadão que procure obe- 
decer à lei. Em certo caso, uma agência estadual foi autorizada a classificar companhias telefônicas em urbanas ou rurais, e as responsabilidades financeiras destas dependiam da classificação. Uma companhia pequena requereu à comissão para ser classificada como rural, e recebeu um ofício em papel timbrado da comissão, assinado em nome desta por seu secretário, declarando que a central telefônica da companhia podia ser classificada como rural e que à mesma era lícito "governar-se de acôrdo com as instruções que regulavam tal classificação". Depois de agir nesta base, durante alguns anos, foi a companhia processada como exploradora de estação central urbana, porque não havia ordem autêntica do departamento, mas apenas declaração de seu secretário, a qual não dava a entender estar autorizada pelo departamento (embora viesse assinada em seu nome por seu secretário), nem indicava quem autorizara o secretário a fazer a declaração.

Da mesma forma, numa série de casos recentes, nos quais foram tomadas sérias providências contra pequenos estabelecimentos de negócios, por parte de comissários auditores da O.P.A., verificou-se, ao serem revistas pelo tribunal, que não houvera violação intencional - um empregado da casa de negócio telefonara à repartição local e fôra mal aconselhado por algum funcionário da agência administrativa quanto ao que havia de fazer. Agir de acôrdo com êsse conselho foi considerado negligência repreensível.

Informaram-nos de que muitos juízes federais se recusam a conceder suspensões de execução judicial por solicitação da O.P.A. em tais casos; não obstante, costuma-se afirmar que as ordens de suspensão não podem ser embargadas pelos tribunais. Como uma das vantagens do regime administrativo é dar pareceres a prioti, ao passo que os tribunais só podem agir depois de ocorridos os fatos ou suscitadas as controvérsias, fàcilmente se presume que as agências administrativas, em tais casos, são muito mais passiveis de negligência do que as partes que lhes fazem pedidos de consulta, e que, por isso, as agências deviam fiscalizar mais severamente os seus subordinados, em deferência à imparcialidade para com o cidadão, em vez de visar exclusivamente a uma política de máxima imposição de seus regulamentos.

Nos piores dias da história judiciária da Inglaterra, na época dos Stuarts, quando a magistratura era dominada pela política, isto é, quando os juízes eram demitidos e nomeados segundo as exigências das causas nas quais a Coroa estava interessada, era muito comum cometerem-se injustiças clamorosas, como acontecia em relação àqueles a quem o rei perseguia. Depois de 1688 , entanto, isto cessou. De então para cá, os tribunais de direito consuetudinário se têm caracterizado pela mais rigorosa imparcialidade, no tocante à plena 
audiência de ambas as partes, nada ocultando que não possa ser explicado ou refutado por uma delas, e proporcionando a todos iguais facilidades para a instrução de suas causas.

Mas, sem nenhuma intenção de serem injustas, as agências administrativas têm manifestado, em sua atuação, uma parcialidade característica. A preocupação de executar meticulosamente a função especial que lhes foi cometida, leva-as a exagerar a importância de sua tarefa específica e a considerar como indignos de atenção os direitos individuais, as garantias constitucionais, e as leis do país. São encorajadas nisso por muitos mestres de direito e pelo govêrno, que adotam o que chamam um ponto de vista realístico em relação ao direito.

Eminente professor de direito administrativo diz-nos que a pedra de toque das decisões administrativas é a política vigente, e não o senso de imparcialidade. Um alto funcionário do govêrno já insinuou que o Congresso admite que uma agência administrativa deva ser parcial. Tal coisa jamais seria tolerada pelos tribunais. Porque são tribunais, espera-se que façam a todos uma distribuição correta e equânime de justiça.

O Sr. W. D. Mrtchell, em seu discurso, por ocasião do $1500^{\circ}$ aniversário da Suprema Côrte de Justiça de Massachussetts, referiu haver observado, quando ainda era procurador geral, a parcialidade dos subordinados do Departamento de Justiça, que pareciam julgarse no dever de tratar parcialmente aquêles com quem o govêrno estava disputando nos tribunais. Quando essa tendência surge em departamentos com amplos poderes de decisão quase-judicial, os resultados costumam ser particularmente maus. As monografias preparadas para a Comissão de Processo Administrativo, nomeada pelo Ministro da Justiça, expuseram algumas proposiçóes muito unilaterais quanto a citações judiciais. As regras e prática, neste particular, são quase sempre parciais, embora isso tenha sido repetidamente demonstrado. Em geral, parece que os regulamentos são elaborados na hipótese de que a causa contra o acusado já tenha sido deliberadamente preparada, sendo, pois, um desperdício de tempo permitir-se-lhe o direito de ampla defesa. limitadíssimo o conceito de imparcialidade, no tocante às relações entre o govêrno e o cidadão. Os interêsses das pessoas privadas são tidos como não merecedores de atenção, por parte do zêlo excessivo das agências administrativas em conseguirem resultados. A tendência é fazer pender o processo, acentuadamente, em favor do govêrno ou do departamento, e presumir que os acusados estão agindo como simples obstrucionistas, ou são-malfeitores-de grande-fortuna, e que ouvir as suas razões não passa de mera formalidade. Muitos exemplos podem ser encontrados nos repertórios oficiais, nos quais a causa foi debatida sob um 
aspecto, e, depois, decidida sob outro, relativamente ao qual o acusado não foi ouvido.

Para citar alguns casos dos repositórios de 1943, lembraremos aquêle em que um inspetor da Junta Nacional das Relações Trabalhistas fêz "esforços persistentes e parciais para conduzir os debates a uma decisão favorável à Junta", considẹrando-se, como assinalou - tribunal, "um agente da Junta especialmente designado para sustentar as acusações desta contra a parte contrária". O tribunal declarou: "Tal atitude, escusável, se não recomendável, em um promotor público, é de todo imprópria em um juiz ou inspetor que assume função judicial para ouvir e julgar fatos, traçar conclusōes de direito, e fazer relatórios e recomendações baseados nisso". A Junta "aprovou todos os atos e a conduta do inspetor, absolveu-o de parcialidade ou prejulgamento, aceitou todos os seus vereditos, tirou conclusões de direito, e fêz relatórios nisso baseados". O Tribunal Regional de Apelação anulou a ordem e devolveu o caso à Junta "para que aos acusados seja concedido amplo e imparcial julgamento, como thes é garantido por lei".

Em outro caso, no mesmo volume, o Tribunal Regional de Apelação disse de uma decisão da mesma agência administrativa: "é simplesmente um mandado e não um veredito". Por isso, daquele volume, que compreende sòmente junho e julho de 1943, constam três ordens daquela Junta que foram anuladas ou modificadas. A referida agência administrativa já havia alcançado triste relêvo nesse assunto de parcialidade. Por exemplo, foi demonstrado que um julgador da Junta, durante um inquérito, conferenciou todo um dia com o procurador do julgamento, o procurador regional da Junta e o diretor regional como se um julgador, na ausência do acusado, devesse manter uma tal conferência com o procurador do processo, o promotor e o procurador geral. Se um juiz assim procedesse, seria, provàvelmente, denunciado, ou a legislatura formularia pedido ao governador para demiti-lo. Quando funcionários administrativos fazem tais coisas, um tribunal revisor pode anular'a ordem resultante. Porém, isso é tudo. Tal é a diferença entre o que se espera de um juiz e o que se espera de uma agência administrativa.

Não tem sido única a êsse respeito a Junta Nacional das Relações Trabalhistas. No mesmo volume do Federal Reporter (segunda série), lemos os seguintes casos: uma ação arbitrária de um subordinado do Departamento dos Correios, que destruiu um vale de encomenda postal; uma determinação discricionária por parte do Tesouro; uma fixação arbitrária de "limites falsos e artificiais" por um funcionário administrativo, baseado "numa certa doutrina de sua própria autoria"; e, finalmente, um regulamento da Junta de Seguro Social contrário à lei. Quando, em dois meses, seis ordens de 
importantes agências administrativas tiveram de ar anuladas por tribunais benevolextes, dispostos a defender, ao máximo, a ação administrativa, não se poderá dizer que não é + leciso manter sob contrổe essas agencias.

Perigos do exercício da função jurisdic nal pelas agências administrativas - porque as agências admi strativas não desenvolveram um espírito característico quanto i suas funções quasejudiciais, a falta de efetivo contrôle sôbre o jrocesso administrativo e as decisões administrativas assume aspec ${ }^{\dagger}$ particularmente grave. Nada hă, em nosso direito administrativo, que se assemelhe a uma! petição inicial ou libelo, com os quais a o lem a ser dada deva conformar-se.

Além disso, como princípio geral, sode-se saber, com antecedência, quais as rormas e a orientaçz̃ a serem aplicadas por um tribunal regular à causa de qualquer jessoa. E, todavia, tendência característica das agências adminis ativas da atualidade darem como fundamento de decisão princí jios não encontrados na lei, ou no direito geral, nem mesmo em qu lquer regra preestabelecida pela agência. Alcançará seu resultado poiada em base extra-legal para o caso particular, base essa que $r$.o é obrigada a observar no próximo caso, mas que justifica, apoia ${ }^{\circ}$ em alguma orientação jamais estabelecida ou declarada. Para itar um exemplo dos repositórios atuais, a Côrte Suprema dos $E^{\prime}$ Ados Unidos, ao examinar, no último ano, uma ordem do S.E.C., eve de relembrar à comissão que, "para as transações, de outro modo legais, poderem ser condenadas, ou negadas as suas conseqüências comerciais, devem estar sujeitas à proibição formal prescrita por normas baixadas por algum órgão de govêrno, autorizado a prescrevê-las - os tribunais, o Congresso, ou uma agêneia à qual o Congresso tenha delegado sua autoridade". No caso particular demonstrou que o Congresso não havia proibido a transação questionada, nem fôra ela condenada por doutrina judiciária firmada, nem havia a comissão, de acôrdo com a sua autoridade delegada, promulgado qualquer norma a respeito do assunto.

Não menos grave é a tendência enraïzada para resolver controvérsias prèviamente, algumas vêzes por uma investigação levada a efeito para provar um resultado obtido de antemão, como no caso de um investigador receber uma lista de pessoas a entrevistar, organizada por uma parte litigante, ou no caso, que presenciei, de um investigador explicar, aos que possuiam pontos de vista próprios, que sòmente estava interessado, sòmente isso relataria, no que the fôsse declarado pelos que adotassem determinado ponto de vista. Em tais investigações ou, de qualquer modo, em investigações conduzidas por seus subordinados, segundo suas instruçōes, algumas 
dessas agências, se a tanto são obrigadas, procedem a um inquérito formal, como satisfação às exigências legais, no qual a parte inquirida é, com efeito, chamada a provar sua inocência. Mui comumente, há uma tendência para se tomarem decisões contrárias às partes, sem ouvi-las, ou baseando-se em relatórios secretos, que as partes interessadas não têm oportunidade ampla para explicar ou refutar. E comum tomar decisões sem prova, ou contra a própria evidência dos fatos, baseando-se em intuição ou convicção pessoais.

Nos repositórios do último ano, encontram-se muitos casos de agências administrativas haverem tomado decisões ou expedido ordens sem base nos fatos. Num caso típico, o tribunal fêz notar que os autos "eram destituídos de qualquer prova" que servisse de base para a decisão, e que não havia prova da qual se pudesse tirar uma inferência sôbre o fato alegado. Noutro, uma decisão da Junta Nacional das Relações Trabalhistas foi considerada "sem apoio em prova". Em outro, uma decisão da Comissão Federal de Comércio foi anulada, porque não se baseava em prova substancial. Noutro, a Comissão Federal de Energia Elétrica, no dizer do tribunal, "usou de uma espécie de teoria do defenda-se como puder" (a sort of catch-as-catch-can theory), e sua atitude consistiu em nada mais, nada menos do que "adivinhar um elemento de valor substancial para o caso". Ainda em outro, o Ministro da Agricultura impôs, arbitràriamente, a um negociante de leite, estabelecido em Boston, "a ubrigação de responder por leite que jamais vira, nem tocara, e que jamais alcançou o mercado de Boston, e com cujos fornecedores não tinha relação contratual de espécie alguma".

Com efeito, certo número dessas agências, pelo menos, arroga-se autoridade para descrer da evidência do que é positivo, incontestado, e não de todo improvável. Como os tribunais têm proclamado muitas vêzes, permitir nisso é investir os julgadores de fato de autoridade para desconsiderar as leis que protegem a liberdade e a propriedade do cidadão. Como declarou um tribunal de apelação da Califórnia, em outubro último:

"As causas não podem ser legalmente decididas com base em opinióes pessoais dos que arcam com essa responsabilidade, e as decisões legais devem ser tomadas com base em uma resolução judicial, alicerçada em prova legal e em reconhecidas regras de direito. Nem jurados nem juízes, quando agindo como árbitros, têm permissão para basear suas decisões na existência ou inexistência de fatos que estejam de acôrdo com suas conviç̧ões e experiências, mas somente em fatos fundados em prova legal e competente ou em deduções que se possam tirar de tais fatos, provados de acôrdo com o direito. A opinião pessoal do juiz não reflete, necessàriamente, a opinião jurídica do tribunal. A opinião pessoal pode - e, algumas 
vêzes, o faz - não consirierar o direito, porém a sentença judiciária depende, para sua exati lão e firmeza, de princípios expressos de direito e de regras defin las de processo."

E-nos lícito suspe ar, algumas vêzes, que os tribunais são por demais escrupulosos, a im de que possam ser inteiramente imparciais para com o indivídur e não tomem resoluções desfavoráveis a êle sem garantia de prc a pùblicamente produzida e de grande valor comprobatório. Tod via, entre êsse fato e o desprêzo pela prova, isto é, agir com bas : em intuição ou pressentimento, ou em investigação unilateral nấ $j$ sujeita a minucioso exame, refutação ou explicação, e basear os zereditos, não em provas, mas em orientação politica - não pode haver dúvida quanto à forma preferida por nossa organização jurír co-constitucional.

Nos últime dez anos, os tribunais têm sido muito liberais em prestigiar, ao $r$ tximo, e onde quer que seja possivel, os atos administrativos. $\mathrm{Di}^{\prime}$ z um juiz federal, no último verão:

"Os age tes administrativos tornaram-se tão numerosos, e o govêrno, pel regulamentação, tornou-se tão extensivo, que os tribunais - é p: recear - podem ir, aos poucos, cedendo à sua crescente influf icia e talvez acabem por permitir que os direitos do povo sejam des ${ }^{4}$ uídos ou submetidos a contrôle por meio de regulamentações, - resultado nunca almejado pela Constituição, hoje em dia manifest mente encarada como instrumento fora de moda."

Qv indo se tem em mente a atual atitude dos tribunais, e se record que, à vista das dificuldades e do custo para se conseguir a revi ăo judicial, sòmente uma parcela diminuta da ação administrativa arbitrária é que chega até aos tribunais e, portanto, aos repositótios, o número de casos (seis em três meses, no último verão) em que os tribunais federais se viram obrigados a anular decisões ar itrárias, ou a recusar-se a mandar cumpri-las, é, em realidade, a amente significativo.

Abuso dos poderes administrativos - Um dos mais graves aspectos da decisão administrativa é o de que as agências administrativas agem como juízes de causas nas quais são também autores, e assim, com efeito, agem como juizes em causa própria. Muitas dessas agências acolhem queixas, empreendem investigações sôbre as mesmas, iniciam como que verdadeiros processos perante elas mesmas, permitem que seus próprios subordinados ajam como advogados no processo, e, muitas vêzes, proferem as decisões em consulta com êsses mesmos subordinados. Tudo isso contraria o mais elementar e universalmente reconhecido princípio de justiça. Tão firmenente baseados nesse princípio estavam os juizes de direito consuetudinário, que em nada menos de quatro causas entre Cook e Holt os 
tribunais decidiram que nem mesmo uma lei do Parlamento poderia fazer de alguém juiz em causa própria. Assim se manifestou um tribunal americano:

"Um dos direitos assegurados ao réu, pela lei do país, é o do que o seu acusador não será ao mesmo tempo o seu juiz; isto é um princípio fundamental de direito; é o primeiro requisito para um julgamento correto e imparcial; é um privilégio que a lei do país garente a todo homem, quando a sua vida, sua liberdade, seu bom nome, sua reputação e propriedade estão empenhados."

Dizem-nos, contudo, que de outra maneira não podem as agências administrativas exercer as suas funções de investigação, bem como as de decisão. Porém, concordo que as suas funçōes de investigação podem ser desempenhadas por métodos que concedam pleno inquérito a ambas as partes e ampla oportunidade aos investigados para conhecer, refutar ou explicar tudo aquilo que deva ser empregado contra êles, e que, se depois da investigação a agência administrativa deseja intentar processo, deveria ser exigido que assim o fizesse nos tribunais e não perante ela mesma.

A Declaração de Direitos de Massachussetts estabelece: " $E$ direito de todo cidadão ser julgado por juízes tão livres, imparciais a independentes quanto o permitir a sua condição humana." Deve isso servir de garantia apenas pelo que diz respeito aos tribunais judiciários, ou será que se não aplicará com mais propriedade aos tribunais administrativos, onde não prevalece a ética da decisão, nascida de longa experiência, e onde as formalidades que acompanham a ação judicial nos tribunais de jüstiça estão ausentes?

Em causas que têm subido aos tribunais, relativamente às agências administrativas federais e estaduais, manifestam-se tendências que exigem revisão judicial eficaz; por exemplo: a tendência para dar aos subordinados, incumbidos de conduzir os inquéritos, instruções secretas que não se acham à disposição do público, coisa que não seria tolerada num tribunal; a tendência para delegar a verdadeira decisão de causas aos subordinados, em vez de deixá-la a critério de chefes responsáveis; a tendência para delegar amplos poderes a subordinados, nem sempre de alta capacidade, sem buscarem controlar êsses subordinados no tocante ao seu trato com o cidadão, ou sequer supervisionarem sua ação a êsse respeito; a tendência para obstruir e embaraçar a ampla apresentação da causa contrária à reclamação da agência que está julgando, e - tanto quanto pode a agência - para embaraçar ou negar recursos aos tribunais, retenção de ordens, e reconsideração de despachos, quer pelo uso do poder de regulamentação, impondo condições onerosas, quer exercendo pressão junto aos tribunais, por meio de doutrinas que restringiriam ou tornariam ineficazes os contrôles existentes. 
Alguns departamentos governamentais sustentaram e conseguiram que importante tribunal federal afirmasse que, "quando uma agência administrativa reclama suspensão de execução forense para fazer cumprir a sua ordem, os tribunais são obrigados a concedê-la sem aplicar os princípios gerais de eqüidade relativos a tais suspensões", princípios que seriam observados nos demais casos. A reclamação feita pelo govêrno em favor da comissão, nesse caso, transformaria os tribunais, na realidade, em simples instrumentos de aprovação burocrática, funcionando como se fôssem verdadeiros "carimbos de borracha" para os departamentos. A Côrte Suprema dos Estados Unidos, tomando essa decisão em fevereiro de 1944, não estava desejando ir tão longe. Deixou, entanto, ao tribunal, margem pequeníssima para a aplicação dos princípios de eqüidade estabelecidos, devolvendo o caso para consideração ulterior pelo Tribunal Regional de Apelação, ao invés de restabelecer o édito do tribunal federal inferior, negando a suspensão da execução.

Quanto à atitude relativa ao inquérito, encontram-se numerosos exemplos nos repositórios de decisões dos tribunais federais, e, positivamente, muito mais ainda nos repositórios estaduais no tocante às agências administrativas dos Estades. Exemplos podem ser notados nas monografias submetidas à Comissão do Processo Administrativo, nomeada pelo Ministro da Justiça. Com efeito, essa Comissão foi unânime em informar que a citação era, as mais das vêzes; incompleta, e que as agências administrativas deixavam, completamente, de prevenir os acusados acêrca daquilo que deviam conhecer, a fim de pcderem preparar adequadamente as suas defesas. Porém, conquanto já o relatório de 1941 insistisse em que a citação devia, de maneira imparcial, "indicar aquilo que o acusado devia conhecer", - O.P.A., ao adotar regulamentações quanto ao processo, não levou em conta essa advertência; e, em junho de 1943, a comrissão da Ordem dos Advogados de São Francisco afirmou que as providências para citação e inquérito eram positivamente inadequadas. Após havèr sido êsse relatório discutido entre a comissão e representantes co O.P.A., e feita uma exposição final em novembro de 1943, sendolhe dada ampla publicidade em dezembro, o O.P.A., em 6 de março de 1944, elaborou novas instruções, modificando-as no sentido de evitar algumas das graves possibilidades de abuso. Essa nova regulamentação, porém, não teve a sorte de entrar em vigor senão em 1 de abril de 1944, de modo que o processo inadequado foi mantido muitos meses depois de plena menção de seus traços condenáveis.

Quão obstinada é essa resistência às exigências de inquérito imparcial, pode-se fàcilmente ver em um caso no qual, embora a lei expressamente exigisse um inquérito, a Comissão do Carvão Betuminoso (órgão federal) baixou ordens, sem notificação ou inquérito, 
e procurou conseguir, do tribunal, decisāo que declarasse desnecessários tais requisitos. A aversão das agências administrativas federais a ouvír ambas as partes é plenamente demonstrada nas monografias preparadas para a comissão nomeada pelo Ministro da Justiça, reunidas no relatório dessa comissão, e no depoimento tomado perante a subcomissão do Senado, encarregada de estudar os projetos de lei propostos naquele relatório. Entretanto, depois de tôda essa discussão, e de muitas coisas mais, contidas em publicações jurídicas e relatórios de institutos de advogados, ainda se fêz necessário, em 1943, que a Côrte Suprema dos Estados Unidos lembrasse à Junta Nacional das Relações Trabalhistas que "não se pode dizer que as decisōes sejam tomadas com imparcialidade, sem que os elementos que as poderiam impugnar, ou aquêles que as apoiariam, hajam sido ouvidos e ponderados." Em um caso, exposto nas monografias preparadas para a comissão nomeada pelo Ministro da Justiça, a agência administrativa opôs-se aos inquéritos porque receou que, se fôsse obrigada a proceder a um, poderia ficar sem sustentáculo para sua decisão, se contestada em tribunal. Embora as leis usualmente prescrevam os inquéritos, as agências administrativas entendem que os mesmos não devem possuir influência controladora sôbre decisões concernentes a fatos. Nas palavras de TERENCE Mulvaney, um inquérito é considerado como "exigência absurda e supérflua". O efeito prático dessa atitude é colocar o indivídưo ou emprêsa particular à mercê dos subordinados das comissões e departamentos.

Realmente, as agências administrativas se esforçam para extinguir ou restringir muito o exame judicial de sua conduta. Em uma série de casos, conseguiram impor o princípio de que as decisões administrativas não podem ser revistas, senão quando o Congresso as torne suscetíveis de revisão. A êsse respeito, o juiz Reed, seguido pelos juízes Roberts e Jackson, discordando, disse:

"Parece mais de acôrdo com o espírito de nossas instituições presumir... que, na ausência de estipulação expressa em contrário, o Congresso tenha pretendido que a autoridade judicial geral, conferida pelo Código de Justiça, fôsse utilizável por um sindicato e seus membros, molestado por uma decisão administrativa presumidamente irreconciliável com um direito estatutário, tão explìcitamente enunciado como, por exemplo, o direito de contratar por intermédio de representantes, escolhidos pelos próprios empregados."

Em outro caso, em que se sustentava haver o Congresso eliminado a revisão judicial, o juiz Murphy, discordando, disse:

"Que um indivíduo definhe na prisão, durante cinco anos, sem que the seja dada a oportunidade de provar que o processo se baseou em ato administrativo ilegal e arbitrário, não está em harmonia com os altos padrões de nosso sistema judiciário." 
Mais, ainda, quando regulamentações promulgadas pela F.C.C., no exercício de seu poder de expedir normas, foram contestadas, por ultrapassarem a autoridade legal da Comissão, esta argumentou que essa regulamentação não podia ser revista judicialmente até que se provasse o prejuízo irreparável da parte que procurava a revisão. A Côrte Suprema dos Estados Unidos, por seis votos contra dois, declarou a ação procedente para proibir a regulamentação. Entretanto, um juiz, adotando o ponto de vista da Comissão, argumentou que, "mesmo que a Comissão perpetrasse uma injustiça", não havia recurso aos tribunais, a menos que o Congresso o estipulasse.

Durante longo tempo, estêve em voga o costume de os funcionários jurídicos de repartições públicas cooperarem nos processos de verificação, sempre que indivíduos desejavam contestar a constitucionalidade da legislação contrária a seus interêsses. No atual regime administrativo, isso, todavia, não se verifica. Uma firma de negócios, ou emprêsa, pode achar-se sèriamente ameaçada por um dispositivo estatutário ou regulamentar, que julgue ser inconstitucional ou ilegal, podendo, entretanto, permanecer indefinidamente nessa situação até que chegue a algum ajuste, ditado por uma agência administrativa, para livrar-se da vacilação e incerteza. Não é considerado matéria de interêsse público que as partes saibam quais são is seus direitos. Parece que se presume serem os estabelecimentos de $\mathrm{n}_{\mathrm{L}}$ “ócios, e as emprêsas, contraventores típicos, e que os seus direitos são 1. 'is às diretrizes políticas, consideradas pelas agências administrativa o no consentâneas ao interêsse público. A atitude dessas agências no tucante à revisão judicial foi bem definida pelo então presidente da Junta Nacional das Relações Trabalhistas, em um discurso perante um instituto de advogados, em 1939: "As exigências de inquérito imparcial não autorizam uma investigação nas atividades internas da agência administrativa." Declarou também que a Junta instruiu subordinados para preparar repositórios rigorosos. $\mathrm{Se}$ os repositórios provavam um inquérito imparcial, não estaria dentro das atribuições dos tribunais indagar de que maneira êsse resultado fôra conseguido.

Igualmente, algumas agências administrativas sustentavam que, durante a revisão, não poderia haver impedimento de execução de suas ordens, a menos que o Congresso expressamente o estipulasse, outras estabeleceram um processo para conseguir o impedimento de execução, processo êsse que, na prática, se revelou inoperante. Quando a decisão administrativa é aniquiladora de um negócio, uma apelação sem efeito suspensivo não é, absolutamente, recurso. Depois que um Tribunal Regional de Apelação adotou o princípio de que se devia exigir medida legislativa para a suspensão, a maioria da Supremo Côrte dos Estados Unidos não se mostrou inclinada a ir 
tão longe. Sustentou ser justo conceder a suspensão, quando a revisão fôsse admissivel, porém deixou à agência administrativa o critério de concedê-la, ou não, no caso particular. Tanto a defesa como a apelação parecem estar prejudicadas em muitas dessas agências.

O que torna sobremaneira graves essas restriçōes à eficaz revisão judicial, ou negação da mesma, é uma certa tendência das agências administrativas para agir segundo as normas por elas próprias inventadas e não segundo os princípios prescritos em lei, como também para projetar a sua atuação além do que pretendia o Congresso ou a legislatura. E muito fácil dizer que o interêsse público exige ou justifica a atividade extra-legal, ou em violação à lei, e encobrir tudo isso com uma declaração formal sôbre o caso. Em geral, isso se faz em consequiência do exagerado desvêlo em promover supostos fins sociais, com os quais o corpo legislativo não poderia concordar. Isso implica um certo grau de poder legislativo nas agências administrativas, que não é, nem lhes devia ser dado em um sistema constitucional. Com efeito, os mais extremados apologistas do absolutismo administrativo não afirmam que isso se harmoniza com as nossas constituições, federal e estaduais. Dizem, no entanto, que devemos olhar essas coisas "em confronto com aquilo que, atualmente, esperamos que o govêrno faça", e, no esfôrço administrativo para alcançar objetivos sociais, parece que não se espera que o govêrno ou suas agências tratem imparcialmente os individuos, embora o contrário se tenha verificado quando as nossas constituições foram elaboradas. Dizem-nos que a separação constitucional de poderes antecede ao aparecimento da consecução administrativa de fins sociais, não se lhe devendo permitir que permaneça em seu caminho. $\mathrm{Na}$ busca de objetivos extra-estatutários há quase sempre um desvio do critério estabelecido pela lei que criou ou rege a agência. A respeito dessa característica das decisões administrativas, disse o Juiz Learned Hand, no ano passado, que a dificuldade na regulamentação de uma indústria "não justifica um desvio do critério estatutàriamente estabelecido. Sob o pretexto de realizar a sua política, não devemos desconsiderar os meios aos quais a realização dessa politica é confiada".

Com efeito, algumas vêzes essas agências observam os estatutos ou sua regulamentação, ou deixam de observá-los, como lhes é facultado escolher em determinados casos. Num caso recente, no qual um funcionário administrativo negou a aplicação de um dispositivo regulamentar, por motivos que julgou de ordem econômica, assim se manifestou o Tribunal Regional de Apelação:

"Um dispositivo que permita um ajustamento tem fôrça de lei. Se um suplicante cria um caso que se enquadra na forma do dispositivo de ajuste, a denegação, por parte do administrador, do recurso de reparação, deve ser julgada um ato arbitrário. 0 administrador 
deve, por fôrça, conceder a reparação exigida pela cláusula de ajuste, muito embora fique patente, através da experiência, que essa cláusula não foi bem formulada, seja imprópria e perturbe o cumprimento geral da regulamentação. Se tal fôr o caso, o que se tem a fazer é revogar ou emendar a cláusula de ajuste."

No referido caso, lavraram-se contratos confiando-se na cláusula de ajuste. $\mathrm{O}$ administrador julgou-se com o direito de interpretá-la, aplicando-a, ou não, a seu juízo. Isso é o régio poder da administração da justiça, que se supôs haver terminado em 1688. $O$ administrador podia baixar normas com fôrça de lei e dispensá-las quando julgasse conveniente, deixando-as em vigor, caso julgasse necessário aplicá-las mais tarde.

Voltando agora ao poder de regulamentação, seria difícil encontrar algo que estivesse mais em desacôrdo com o govêrno constitucional americano do que a autoridade ilimitada, hoje exercida por muitas agências administrativas e até por seus subordinados. Como declarou o Juiz Miller, falando para a Suprema Côrte dos Estados Unidos, em 1875, "a teoria de nossos governos, estaduais e nacional, é contrária à concessão de poder ilimitado em qualquer parte."

O nosso processo legislativo está sujeito a contrôles eficazes. Suponhamos que um projeto de lei deve ser apresentado pùblicamente. E impresso e pôsto à disposição do exame público. $E$ discutido na imprensa. $E$ entregue a uma comissão parlamentar e, em assunto de importância, inquéritos são realizados. E lido três vêzes perante cada Casa, é debatido pùblicamente em plenário e, depois de ser recomendado por ambas as Casas, é mandado ao chefe do Executivo para aprovação ou veto. Qualquer pessoa cujos interêsses possam ser atingidos tem ampla oportunidade de ser ouvida e de apresentar suas objeções. A regulamentação judicial também toma, cuidadosamente, providências para considerar as reclamações de todos os que possam ser afetados. As normas de tribunal são traçadas por comissões de juizes, advogados militantes e professôres de direito, ou por conselhos judiciários; os projetos são impressos, sendo1hes dada ampla publicidade; são remetidos para crítica a comissões do instituto de advogados, ou a comissões do instituto nas diferentes circunscrições, discutidos perante as associações de advogado e nas publicações jurídicas, e sòmente adotados depois que tôda pessoa interessada foi ouvida.

O poder administrativo de regulamentação está em chocante contraste com os fatos acima apontados. Algumas vêzes as normas e regulamentos administrativos, com fôrça de lei, afetam interêsses de tanta ou maior significação para os indivíduos do que os afetados pelas leis e pelos regimentos dos tribunais. Não há, porém, contrôles 
sôbre o poder administrativo de regulamentação. Habitualmente, $o$ conhecimento que as pessoas atingidas têm de uma norma ocorre depois que a mesma entrou em vigor. A primeira oportunidade que essas pessoas têm para fazer-lhe objeção surge, em geral, depois que se procurou impô-la contra elas, só então lhes sendo possível atacá-la nos tribunais. A êsse tempo, entretanto, danos graves e irreparáveis podem ter sido causados a um indivíduo e a seu negócio. Além disso, a extensão que, hoje em dia, se dá ao poder administrativo de regulamentação é tão vasta que não é fácil e, muitas vêzes, é até desvantajoso, contestar pormenores nos tribunais.

Não se trata, como alguns teriam pensado ser êste o nosso ponto de vista, apenas de uma questão de proteger contraventores afortunados e grandes companhias contra uma regulamentação razoável. A êsses sòmente se concede um certo grau de proteção nas ações para suspensão de execução e também para contestar nos tribunais o cumprimento das regulamentações administrativas. As ações para suspensão de execução são dispendiosas e outros recursos judiciários têm sido grandemente limitados, e na multiplicidade e diversidade dos estatutos e regulamentações é algumas vêzes difícil determinar quais são os recursos e como adotá-los. Trata-se, portanto, de proteger os negócios médios e pequenos, e a pessoa humana. Esses não podem ter os meios para fazer face às dispendiosas ações de suspensão de execução e trazế-las à Côrte Suprema em Washington, por terem a certeza de que a agência administrativa resistirá até o fim, terá uma numerosa equipe de advogados, chefes de departamento, e, muito provàvelmente, funcionários jurídicos a serviço do govêrno e por êle prestigiado. Os pequenos negócios e o homem comum são forçados a entrar em acordos, aceitando deliberações que os prejudicam, além de desprezar os seus direitos. A tendência geral tem sido mostrar grande parcialidade para com negócios e emprêsas individuais. Mais de uma dessas agencias tem parecido enunciar uma política de lançar todos os negócios e indústrias nas mãos do govêrno, ocasionando assim uma revolução econômica.

Não podemos, como sugerem alguns, atribuir o absolutismo administrativo, que se tem desenvolvido nos últimos anos, à emergência da guerra. A situação com que se defronta o nosso sistema constitucional americano fortaleceu-se antes da guerra. Um artigo do Deão Wigmore, publicado em janeiro de 1939 , indicou a enorme multiplicação das agências administrativas federais, seus extensos poderes e a grande dificuldade de verificar seu funcionamento e orientação. Em abril de 1939, o direito administrativo federal foi o assunto de uma reunião, celebrada sob os auspícios do Instituto dos Advogados do Estado da Virgínia, na qual foi chamada a atenção para muito do que tenho estado a falar. Em 3 de agôsto de 1939, o 
presidente do Instituto dos Advogados do Estado da Virgínia proferiu uma conferência intitulada "Direito Administrativo e Liberdade", na qual proclamou a necessidade de urgente promulgação de uma medida da espécie da que o Instituto dos Advogados Americanos tinha então estado a elaborar durante dois anos, tendo em vista aquilo que mencionou como "a atual exigência federal de extenso poder do executivo sôbre a vida e as liberdades de nosso povo." Tudo isso foi anterior ao irrompimento da guerra na Europa e muito antes que entrássemos no conflito. $O$ mais que se pode dizer é que às tendências que tinham sido cada vez mais evidentes durante uma geração e tinham tido um acentuado desenvolvimento durante o regime de proibição nacional, foi dado um ímpeto suplementar pelas exigências da guerra.

Felizmente, institutos de advogados, e especialmente o Instituto dos Advogados Americanos sob a direção do Sr. Henderson, têm estado a tratar dêsse assunto vigorosamente. $O$ recurso quanto às decisões administrativas está na legislação que providencie a salvaguarda dos elementos de processo imparcial e inquéritos imparciais e de um simples e rápido modo de revisão que assegure adesão às limitações estatutárias e afaste a necessidade de revisão por processos de suspensão de execução. Quanto ao poder de regulamentação, uma simples adaptação do processo de sentença declaratória realizaria o que é exigido. Mas a advocacia precisa de agitar-se. Processos tais como os que vimos desenvolvendo pertencem a países que acreditam em govêrno de um onipotente super-homem com uma hierarquia de super-homens às suas ordens, aos quais a vida, a liberdade e a propriedade do cidadão são subordinadas; que são tão oniscientes a ponto de saberem sem demora o que o interêsse público reclama em cada caso e não necessitam de inquéritos, ou prova, ou argumentos, para aconselhar-se, porém devem harmonizar tôdas as relações e prescrever tôda conduta à luz de sua sabedoria ex-officio numa organização política da sociedade que não reconhece direitos privados. Se, como nos dizem os supostos realistas jurídico-políticos recentes, um govêrno é de fato apenas o funcionalismo público do momento, e, portanto, o govêrno de homens é o govêrno de seres humanos que podem agir levados pela maior variedade de motivos, conveniência política, preconceito, despeito, zêlo errado, e podem ser por vêzes imparciais e outras cruéis e desarrazoados, é óbvio o resultado a que pode chegar uma teoria do direito como sendo tudo o que seja feito oficialmente.

O culto da fôrça tem-se espalhado por todo o mundo. Em lugar do princípio político e jurídico em que se fundou o nosso govêrno, e segundo o qual a América se desenvolveu a ponto de ser uma terra para a qual os povos de tôda parte do mundo têm estado ansiosos 
para vir, a fim de levar a existência de homens livres, e gozar a vida, a liberdade e a propriedade em segurança, novos princípios têm sido suscitados. Ao invés de nossa doutrina fundamental de que o govêrno deve ser conduzido de acôrdo com o direito, dizem-nos que aquilo que o govêrno faz é direito. Ao invés de um direito que considera os cidadãos e os funcionários como igualmente sujeitos à lei, falamnos de um direito público que subordina o cidadão ao funcionário e permite que êste ponha as reclamações de um cidadão sôbre as de outro, não de acôrdo com alguma regra geral de direito, mas de acôrdo com as suas idéias próprias ao momento. Uma filosofia da resignação do direito e do govêrno está sendo largamente ensinada. Dizem-nos que o direito deve desaparecer na sociedade do futuro. Falam-nos de uma sociedade na qual um govêrno todo-competente e benevolente proverá à satisfação das necessidades materiais de tôda gente e não haverá necessidade de conciliar relações ou prescrever orientação do direito, uma vez que todo o mundo estará satisfeito. Portanto, não haverá direitos. Haverá sòmente um dever geral de obediência passiva. Precisamos estar vigilantes, enquanto combatemos regimes dessa espécie que se desenvolveram em ditaduras e governos totalitários, para não permitir que um regime de departamentos burocráticos se implante em nosso país a ponto de levar-nos à mesma direção. 